\title{
Memórias e histórias da comunidade Quilombola Orquídio Pereira
}

\section{Memories and history of quilombola comunity Orquídio Pereira}

\section{Benedito Eugenio}

iD http://orcid.org/0000-0002-5781-764X Universidade Estadual do Sudoeste da Bahia dodoeugenio@gmail.com

\section{Milena Lima Tamborrielo}

D http://orcid.org/0000-0003-3071-5659 Rede Estadual de Ensino da Bahia mi_tamborrielo@hotmail.com

\section{Rúbia Cristina Nóbrega}

http://orcid.org/0000-0002-0809-1512 Programa de Pós-Graduação em Relações Étnicas e Contemporaneidade rubiacrisnobrega@hotmail.com

\section{Juliana Brito dos Santos}

http://orcid.org/0000-0001-8634-1874 Programa de Pós-Graduação em Relações Étnicas e Contemporaneidade juli-britto@hotmail.com

DOI: 10.22481/odeere.v5i9.6613

\section{RESUMO:}

Os estudos sobre as comunidades quilombolas tem se ampliado significativamente nos últimos anos no Brasil. Áreas como História, Sociologia, Antropologia, Educação têm evidenciado, com diferentes enfoques teóricos e metodológicos, a importância de se compreender as dimensões histórias, culturais, educacionais dessas comunidades. Neste artigo apresentamos aspectos da história e memória da comunidade quilombola Orquídio Pereira. Os dados foram construídos por meio de entrevistas com moradores antigos e nos permitiu entender as memórias de moradores em uma perspectiva benjaminiana.

Palavras-chave: Memória. Narrativa. Comunidade quilombola.

\section{ABSTRACT:}

Studies on quilombola communities have expanded significantly in recent years in Brazil. Areas such as History, Sociology, Anthropology, Education have shown, with different theoretical and methodological approaches, the importance of understanding the historical, cultural and educational dimensions of these communities. In this article we present aspects of the history and memory of the quilombola community Orquídio Pereira. The data were constructed through interviews with former residents and allowed us to understand residents' memories from a Benjamininian perspective.

Keywords: Memory. Narrative. Quilombola comunity. 


\section{Introdução}

"Esse mundo não era assim não, não tinha nada, só tinha era mata mais..." (Entrevista Tio João)

Este artigo apresenta os resultados de um projeto mais amplo de pesquisas que temos realizado sobre as comunidades quilombolas no Estado da Bahia, suas práticas pedagógicas e curriculares e a interface com as relações étnico-raciais.

Na pesquisa desenvolvida no período de 2008-2009 investigamos as relações entre memória, identidade e educação em uma comunidade quilombola localizada no município de Vitória da Conquista-Ba. Já na pesquisa realizada entre 2011 a 2015 efetuamos um mapeamento das comunidades quilombolas nos territórios de identidade do Sudoeste e do Extremo Sul baianos. Desde 2015 ampliamos a área de abrangência de nossa pesquisa, o que resultou em orientações de dissertações de mestrado e publicações de artigos e capítulos de livro discutindo diferentes questões da educação escolar quilombola.

Levantamento preliminar efetuado no site dos programas de pós-graduação em Educação da UFBA, UEFS e UNEB e nos programas de Estudos Étnicos e Africanos (UFBA) e Relações Étnicas e Contemporaneidade (UESB), assim como no site Domínio Público, tendo como espaço o Estado da Bahia, revelaram que a temática dos quilombos/quilombolas vem sendo pesquisada em diferentes campos do conhecimento, principalmente no grande campo das Ciências Humanas (Antropologia, História, Sociologia, Interdisciplinar).

No campo da Educação, vem se ampliando o quantitativo de pesquisas nessas comunidades. No caso específico do Estado da Bahia, esse levantamento evidenciou que a UNEB e UFBA são as instituições com maior número de pesquisas. No caso da UFBA, essa instituição foi por muitas décadas a única a ofertar pósgraduação strictu sensu no Estado, motivo pelo qual atribuímos o maior número de pesquisas.

Mais recentemente tem se destacado a UESB no estudo das comunidades quilombolas, particularmente nas pesquisas realizadas no programa de Pósgraduação em Relações Étnicas e Contemporaneidade, aprovado em 2014 e que já conta com 11 dissertações concluídas relacionadas às comunidades quilombolas, além de um curso de extensão específico sobre comunidades 
quilombolas. Uma abordagem inicial sobre esse curso de extensão pode ser encontrada em trabalhos como o desses autores'.

No caso da UESB, as pesquisas tem abordado como temáticas prioritárias: etnicidade e infância quilombola, processos de escolarização de jovens negros quilombolas, formação de professores de escolas quilombolas, conhecimentos tradicionais, masculinidades, produção da identidade quilombola.

Estudos que reconstroem aspectos da historicidade de comunidades quilombolas na Bahia, a exemplo de ${ }^{2}$ contribuíram para a escrita deste texto. Neste artigo apresentamos aspectos da história e memória da comunidade quilombola de Landoufo Porto valendo de fontes orais por meio das memórias dos moradores antigos.

\section{Benjamin e a compreensão de memória}

Vários estudiosos dedicaram-se a entender questões relativas à memória. Destacamos aqui as contribuições das formulações benjaminianas na discussão da temática. Seixas ${ }^{3}$, ao retomar a discussão de memória versus história, nos sinaliza como a discussão está sendo pontuada atualmente. Segundo esta autora, nos anos 1980 a historiografia toma consciência de que a relação memória-história é mais uma relação de conflito e oposição do que de complementaridade. Ao mesmo tempo, a história se coloca como produtora de memórias. Essa oposição é construída, sobretudo, com base na tradição aristotélica, que entende a memória como conhecimento do passado.

É com a sociologia que a historiografia contemporânea sobre memória tem traçado os seus diálogos mais fecundos, principalmente com Halbwachs. Quem se apropria desse referencial é Pierre Nora, que elabora a divisão e oposição entre memória e historia. Para Nora, a memória é a tradição vivida, é a vida, enquanto que a história é uma representação crítica e sistematizada do passado. Sendo assim, a memória é prisioneira da história.

No caso da historiografia anglo-saxônica, trilha-se um caminho diverso da

\footnotetext{
1 Dócio e Perovano Filho (2019)

2 Ferreira (1999), Oliveira (2010), Oliveira (2012), Lima (2018)

3 Seixas (2001)
} 
historiografia francesa. No caso daquela, a memória é aproximada em demasia da noção de história. Acaba-se por não se reconhecer uma distinção clara entre memória e história4. Elas acabam por se identificar. Toda memória é imediatamente história. Contribuição importante também é oferecida por Benjamin, para quem o papel do historiador é o de intérprete dos sonhos coletivos. Recorrer ao passado pressupõe um retorno à memória. Benjamin ocupa-se com o trabalho da memória em vários escritos: a série radiofônica sobre Berlim (1929-30), a Crônica Berlinense (1931-32) e Infância em Berlim por volta de 1900 (última versão de 1938).

A teoria benjaminiana de memória apropria-se dos seguintes conceitos: memória, recordação, lembrança, memória voluntária e involuntária, traço mnemônico, rememoração, vivência e experiência.

Benjamin analisou o significado da memória a partir das reflexões de Henry Bergson, principalmente com as relações existentes entre matéria e memória. Mas o autor berlinense também criticou algumas considerações bergsonianas, como a tentativa daquele de fundir no seu conceito de memória dois tipos de experiência que não se adequavam mais ao mundo moderno. Em Benjamim, a memória faz parte da experiência humana da modernidade, sendo que ela é contextualizada.

Outra referência importante no trabalho benjaminiano de memória é Marcel Proust. Três pontos da obra deste foram decisivos para Benjamin: o trabalho da memória involuntária e sua relação com o esquecimento; a dimensão da eternidade proustiana, que não é a de um tempo linear ilimitado; as semelhanças captadas num "estado de sonho" e incorporadas à existência vivida.

A importância da lembrança (Erinnerung) para Benjamin vem com essa leitura de Proust. Ele considera que em Proust o importante para o autor que lembra não é o que ele viveu, mas o tecido da sua lembrança, o trabalho de Penélope da rememoração (Eigendenken).

Mas Benjamin, ao mesmo tempo, distancia-se de Proust já em seus textos autobiográficos por diversas razões. Nesses textos, estabelece um vínculo entre a esfera da rememoração individual e a coletiva. Isso acontece porque ele segue como regra não usar a palavra 'eu' em seus escritos, a não ser nas cartas. Mesmo

\footnotetext{
${ }^{4}$ Seixas (2001)
} 
as lembranças que se referem à sua infância em Berlim não devem ser consideradas lembranças pessoais e nem voluntárias. Também se distancia de Proust por considerar que a rememoração não pode ser mantida como obra do acaso.

Benjamin trabalhou com dois tipos de memória: voluntária e a involuntária. Enquanto a primeira seria aquela que se coloca a serviço do intelecto e que traz para o presente eventos passados pela ação intencional daquele que lembra, a memória involuntária seria aquela em que as experiências anteriormente vivenciadas surgem sem serem produtos de uma ação intencional. À primeira memória associou o conceito de Erlebnis, conceito descrito por Dilthey como sendo a experiência humana da vida.

Enfatizando a condição histórica da experiência humana, Benjamin argumentou que o conceito de Erlebnis não permitia nenhuma percepção de continuidade temporal porque estava restrito à esfera de um tempo determinado da experiência humana. Assim, é na memória involuntária, responsável pela transmissão de experiências vivenciadas no passado através de um continuum temporal, que Benjamin associa o conceito de Erfahrung, que implica em que o único sentido a ser compreendido de experiências já vivenciadas é aquele que pode ser transmitido através do tempo.

A arte de narrar experiências vividas torna-se cada vez mais rara e ele mostra-se preocupado com o silêncio dos homens ${ }^{5}$. Em Experiência e pobreza, ele chama a nossa atenção para os riscos de morte que corre o patrimônio cultural da humanidade devido "ao monstruoso desenvolvimento da técnica". Para isso, baseia-se na experiência vivida pelos combatentes na I Guerra Mundial, que, segundo ele, voltaram "mais pobres em experiências comunicáveis, e não mais ricos"6.

No texto $O$ narrador, escrito em 1936, Benjamin demonstra sua preocupação com a perda da capacidade de narrar dos homens. As mudanças no mundo do trabalho fizeram com que a narrativa perdesse uma de suas ferramentas, o ouvido das pessoas, colocando aquela em vias de extinção. Assim diz o nosso teórico:

\footnotetext{
5 BENJAMIN, 1994.

6 BENJAMIN (1994, p.115)
} 
São cada vez mais raras as pessoas que sabem narrar devidamente. Quando se pede num grupo que alguém narre alguma coisa, o embaraço se generaliza. É como se estivéssemos privados de uma faculdade que nos parecia segura e inalienável: a faculdade de intercambiar experiências? ${ }^{7}$.

A proposta de Benjamin é que narremos, sem distinção, grandes e pequenos acontecimentos, pois a hierarquização dos acontecimentos deixa de lado outros sujeitos que foram derrotados; cada momento é tem algo importante para cada sujeito. Para ele, as melhores narrativas são as que menos se distinguem das histórias orais contadas pelos inúmeros narradores anônimos.

\section{Considerações sobre comunidades quilombolas}

Mesmo após a abolição da escravidão, as formações quilombolas continuam, mas não mais com a mesma intencionalidade da época da escravidão, onde o quilombo era tido como esconderijo para os escravos fugidos?.

Após a constituição de 1988, as comunidades remanescentes de quilombos têm os seus direitos territoriais concedidos legalmente, contudo os direitos são conferidos apenas às comunidades quilombolas que tinha descendência direta com ex-escravos ou fossem formações quilombolas que se originaram no período escravista?.

Assim, com a atualização do conceito de quilombo, a lei passou a agregar um maior número de comunidades, incluindo comunidades rurais e urbanas que tiveram a sua origem relacionada com descendentes de ex-escravos ou de negros que não são descendentes dos ex-escravos, mas foram excluídos da divisão latifundiária como todos os outros e que continuam à margem da sociedade brasileira ${ }^{10}$.

Antes de trazer o conceito de quilombo, é necessário compreendê-lo enquanto fenômeno histórico inerente ao sistema escravocrata, que por mais de três séculos predominou como modo de produção no Brasil. O quilombo constituiu "uma das principais alternativas de negação da produção escravista por parte dos

\footnotetext{
7 BENJAMIN ((1994, p. 197-8)

8 FIABANI, 2012.

9 FIABANI, 2012

10 O'DWYER, 2002.
} 
produtores oprimidos"11.

A principal forma de resistência do cativo à escravidão foi à oposição ao trabalho escravizado, por meio do "corpo mole", da sabotagem das ferramentas, do autoferimento etc. [...] Uma não menos significativa forma de oposição à escravidão foi a fuga, pela qual o cativo se libertava das amarras que o prendiam ao escravizador, criando as condições para um exercício autonômico de sua força de trabalho'2.

A fuga dos cativos deu-se, principalmente, por conta das condições subumanas a que estavam submetidos os negros escravizados: "Foi a violência e a opressão que levaram o cativo a se aquilombar"13.

Em toda extensão do território brasileiro, em campos e/ou em cidades, um grande número de cativos fugiam "à procura de um ermo qualquer do interior, nas escarpas de uma serra, no coração de uma ilha, nos embrenhados de um mangue ou na profundeza de uma floresta"14.

Por meio do exercício da antiga sabedoria dos oprimidos, de que se "deus é grande, o mato é ainda maior", procuravam formar uma comunidade de produtores livres em um espaço geográfico e social que, por suas características, estivesse longe do braço pesado do escravista. No Brasil, essas comunidades foram conhecidas no passado como mocambos ou quilombos ${ }^{15}$.

O termo quilombo era usado para se referir às unidades de apoio mútuo que foram criadas pelos rebeldes ao sistema escravista e às suas reações, organizações e lutas pelo fim da escravidão no país, "a palavra 'quilombo', de origem bantu, quer dizer acampamento guerreiro na floresta"16.

Na concepção de 17 os quilombos eram, sobretudo, "[...] locais de encontro de escravos de ganho ou fugidos, onde eles se reuniam para comer, descansar, praticar religião, trocar ou esconder mercadorias roubadas" 18 .

\footnotetext{
11 FIABANI $(2012$, p.23)

12 FIABANI $(2012, p .8)$

13 FIABANI $(2012$, p.171).

14 FIABANI $(2012$, p.11).

15 FIABANI $(2012, \mathrm{p} 11)$

16 LEITE $(2008$, p.965).

17 Arruti (2008)

18 ARRUTI (2008, p.319)
} 
No âmbito do sistema escravocrata, a essência do conceito de quilombo encontrava-se no número de cativos "localizados em um local determinado, com elementos que atestavam a fixação-estabilidade do grupo"19.

Na definição realizada pelo Conselho Ultramarino em 1740, com vistas à repressão de uma das principais modalidades de resistência ao regime escravocrata, o quilombo consta como '[...] toda habitação de negros fugidos, que passem de cinco, em parte despovoada, ainda que não tenham ranchos levantados e não se achem pilões neles'20

No entanto, essa definição que aponta para a situação de fuga para o cativeiro e o estado de isolamento dos escravos tinham como objetivo fornecer parâmetros ao poder constituído "para reprimir com eficácia situações limites (fuga e esconderijo) que comprometiam a continuidade do sistema"21.

Segundo 22 as comunidades de escravos fugidos possuíam um número variável de integrantes e acrescenta que: "[...] o quilombo deve ser compreendido como um fenômeno próprio e específico da luta de classes sob o escravismo. Uma forma de resistência que requer determinadas condições geográficas, demográficas, etc"23.

Assim, "o resgate da importância do quilombo, pelo seu caráter de resistência ao escravismo, nos permite aprofundar a compreensão do escravo enquanto sujeito histórico e localizá-lo como agente da luta de classes no âmbito da sociedade que tem por base a escravidão"24.

O quilombo era fundamental para garantir a segurança dos desertores, para que sua condição de liberdade fosse assegurada. Para25 "[...] o quilombo não se define a partir do local, mas a partir do elemento humano que o integra [...] o que vai definir este ou aquele local enquanto quilombo é a existência, neles, de elemento vivo, dinâmico, ameaçador da ordem escravista, enfim, o escravo

\footnotetext{
19 FIABANI (2012, p.267)

20 MELO et al (2011, p.80)

21 MELO et al (2011, p.80-81)

22 Maestri (1988, apud FIABANI, 2012)

23 Maestri (1988, apud FIABANI, 2012, p.157)

24 FIABANI ( 2012, p.24)

25 Guimarães (1980, apud FIABANI, 2012, p.163-164)
} 
fugido".

O caráter revolucionário da fuga dos cativos e o aquilombamento dos insurretos representam a resistência dos negros escravizados ao regime ao qual estavam submetidos. Nesse sentido26, afirma que "[...] o quilombo foi - objetiva e subjetivamente- o mais fácil caminho para que o escravo permanecesse livre".

Ainda que "agrupar para preservar sua cultura, sua língua, seus cultos, seus cantos, mantendo o sentimento de nacionalidade" 27 fizesse sentido para os cativos fugidos, essa ideia não os motivou a aquilombar-se; o quilombo também servia de local onde aconteciam escambos e transações ilegais, admitindo "a presença de outros elementos além dos cativos" 28 .

Assim, o aquilombamento dos cativos apenas como uma forma de retornar às origens africanas é refutada porque as fontes históricas consultadas apontam para heterogeneidade da população dos quilombos ${ }^{29}$.

Os quilombos subsistiram por mais de três séculos - período correspondente ao regime de escravidão no Brasil - e após a abolição, ocorrida em 13 de maio de 1888, o trabalhador escravizado obteve sua liberdade civil. Contudo, o fim da escravidão não trouxe consigo mudanças expressivas nas condições materiais de existência do afrodescendente.

Alguns quilombolas continuavam vivendo como posseiros nas áreas de seus quilombos. Outros procuravam a sobrevivência juntando-se às parcelas da população marginalizada, em novas formas de luta pela sobrevivência. Com o fim da escravidão o quilombo deixou de existir como entidade gerada no seio e a partir das contradições da sociedade escravista, fruto da resistência do produtor escravizado contra a apropriação de sua pessoa, e, portanto, de sua força de trabalho, pelo escravizador ${ }^{30}$.

No ano de 1988 celebrou-se o Centenário da Abolição da Escravidão e também foi o ano da nova Constituição do país. Como parte da própria reflexão sobre o Centenário da Abolição da Escravidão no Brasil, seguida de reivindicações

\footnotetext{
${ }^{26}$ Guimarães (1988, apud FIABANI, 2012, p.157)

${ }^{27}$ FIABANI (2012, p.171

${ }^{28}$ Guimarães (1988, apud FIABANI, 2012, p.168)

${ }^{29} \mathrm{FIABANI}(2012)$

30 FIABANI $(2012$, p.26)
} 
de organizações de movimento negro e setores progressistas, a Constituição Federal de 1988 trouxe no bojo das suas modificações, a aprovação de dispositivos constitucionais concebidos como forma de compensação à opressão histórica sofrida pelos negros no Brasil. O momento tornou-se propício aos apelos da minoria - que proporcionou uma nova leitura acerca do quilombo, que precisava ser definido para ser titularizado ${ }^{31}$.

Dentre essas modificações, nos interessa no momento evidenciar as medidas relativas aos quilombos ou "Comunidades negras remanescentes de antigos Quilombos", como estão descritas na Constituição Federal de 1988, "vista a tentativa de circunscrever o sujeito deste direito à estrita e explícita historicidade do termo quilombo"32.

Assim, o artigo 68 dos Atos das Disposições Constitucionais Transitórias da Constituição Federal de 1988 (ADCT) estabeleceu que: "Aos remanescentes das comunidades dos quilombos que estejam ocupando suas terras é reconhecida a propriedade definitiva, devendo o Estado emitir-Ihes os títulos respectivos" (BRASIL, art. 68, CF/88).

Essa norma constitucional cria a obrigação ao Estado a adotar as medidas necessárias à transferência da propriedade às comunidades étnicas bem como reconhecer (e não estabelecer) diretamente aos remanescentes dos quilombos a delimitação, demarcação e titularidade das suas terras.

Por remanescente de quilombos se entende hoje todo o agrupamento negro, rural ou urbano, que foi constituído durante o regime escravocrata ou logo após a abolição e que consolidou um território como forma de construção de um espaço mínimo de autonomia, no interior do qual lograram a reprodução econômica, biológica e social em condições adversas ${ }^{33}$

No entanto, "a interpretação estrita do preceito constitucional excluía do reconhecimento da propriedade da terra, através daquela ordenação, toda e qualquer comunidade rural afrodescendente não originada diretamente do

\footnotetext{
31 FIABANI (2012).

32 ARRUTI (2008, p.323)

33 MELO et al (2011, p.21)
} 
quilombo"34.

A fim de estender os critérios de reconhecimento de uma comunidade remanescente de quilombo, para agregar um maior número de afrodescendentes de comunidades negras rurais que não se inseriam nas exigências prescritas no texto constitucional, os antropólogos assumem a discussão, não com o intento de ampliar a lei, mas trazendo à baila ressemantizações do conceito de quilombo.

Os antropólogos, por meio da Associação Brasileira de Antropologia (ABA), fundada em 1955, tiveram um papel decisivo no questionamento de noções baseadas em julgamentos arbitrários, como a de remanescente de quilombo, ao indicar a necessidade de os fatos serem percebidos a partir de uma outra dimensão que venha a incorporar o ponto de vista dos grupos sociais que pretendem, em suas ações, a vigência do direito atribuído pela Constituição Federal35.

A partir de reflexões antropológicas sobre etnicidade, grupos étnicos e diferenças culturais e fazendo uso de materiais de pesquisas etnográficas como tema de debates nesse campo de direitos constitucionais, o conceito de quilombo vem sendo ressignificado (O'DWYER, 2002).

[...] o termo quilombo tem assumido novos significados na literatura especializada e também para grupos, indivíduos e organizações. Ainda que tenha um conteúdo histórico, o mesmo vem sendo 'ressemantizado' para designar a situação presente dos segmentos negros em diferentes regiões e contextos do Brasil (O'DWYER, 2002, p.18)

O quilombo pensado para abrigar escravos fugidos tem o seu conceito atrelado ao fenômeno histórico da sua aparição e por isso as características desses quilombos - constituídos na ocasião do sistema escravocrata - não correspondem ao modelo de quilombo apresentado pelos antropólogos no documento da Associação Brasileira de Antropologia (ABA).

A princípio a divergência reside na composição do quilombo; não são mais os escravos fugidos que buscam refúgio. A intencionalidade com que o quilombo foi pensado também muda: os agrupamentos que se instalaram nesse lócus não

\footnotetext{
34 FIABANI (2012, p.28)

${ }^{35}$ O'DWYER $(2002$, p.18)
} 
mais aspiram pela liberdade dos seus corpos frente o domínio dos seus senhores.

Todavia os agrupamentos descritos como "quilombos contemporâneos"36 são constituídos por descendentes - diretos ou indiretos - de uma geração de negros que vivenciaram a escravidão e todas as suas mazelas, que não tiveram direito sequer a uma porção de terra nem por herança nem por qualquer outro direito adquirido pelos seus ancestrais, sobrevivendo a margem de uma sociedade hierarquizada e discriminadora.

As discussões propostas pela ABA sobre a ressignificação do conceito de quilombo, alargando o conceito para abarcar as comunidades negras rurais que não são necessariamente formações oriundas de antigos quilombos (quilombos históricos), faz-se necessária para contemplar as formações dos quilombos contemporâneos e os seus remanescentes.

A ABA propõe que "os quilombos sejam tomados como grupos que desenvolveram práticas de resistência na manutenção e reprodução de seus modos de vida característicos num determinado lugar" 37.

Para ${ }^{38}$ os grupos que formam os quilombos não se referem à resíduos, não estão isolados, não tem sempre origem em movimentos de rebeldia, não se define pelo número de membros e não fazem uma apropriação individual da terra; evidencia-se nesses grupos suas identidades que se definem por "uma referência histórica comum, construída a partir de vivências e valores partilhados"39.

O conceito contemporâneo de quilombo tem sido concebido com base na auto definição identitária relacionada a uma ancestralidade negra, de sentido coletivo40.

Nas proposições elencadas por ${ }^{41}$ quando o autor aborda os paradigmas do conceito contemporâneo de quilombo, relata que "há a introdução de uma forte ênfase no uso do termo etnicidade para dar conta dos processos sociais e simbólicos vividos pela população negra no pós-escravidão"42.

\footnotetext{
36 O'DWYER(2002)

37 ARRUTI (2008, p. 317).

38 Arruti (2008)

39 ARRUTI (2008, p.317)

40 ARRUTI (2008)

${ }^{41}$ Arruti (2008)

42 ARRUTI ( 2008, p.330)
} 
Enfim, por meio da sua leitura através da teoria da etnicidade, o conceito contemporâneo de quilombo aponta para grupos sociais produzidos em decorrência de conflitos fundiários localizados e datados, ligados à dissolução das formas de organização do sistema escravista ${ }^{43}$.

A categoria etnicidade oferece uma "chave explicativa para os mecanismos sociais de manutenção dos chamados 'territórios negros': elas seriam definidas com base em limites étnicos, desenvolvidos no enfrentamento da situação de alteridade proposta pelos brancos" 44 .

As suposições implicadas no termo quilombo colocam no núcleo de definição daqueles grupos "uma historicidade que remete sempre ao par memória-direitos: em se tratando de remanescentes, o que está em jogo é o reconhecimento de um processo histórico de desrespeito" 45.

Sobre os direitos territoriais das comunidades remanescentes de quilombo:

O processo de reconhecimento dos direitos territoriais das comunidades remanescentes de quilombos é um processo que objetiva resgatar parte da história da resistência negra diante da discriminação, da opressão e do escravismo sofridos pela ancestralidade negra em terras brasileiras ${ }^{46}$.

O artigo 68 da ADTC foi um avanço no que toca o reconhecimento dos direitos "dos negros de ancestralidade africana que trabalham e tem morada habitual no meio rural" 47.

Para ${ }^{48:}$

[...] as ações civis, mobilizações e a criação de associações quilombolas permitiram aos afrodescendentes recompor e reescrever uma narrativa única sobre sua história. Essa história foi convergindo para o quilombo como expressão máxima de luta dos afrodescendentes pela cidadania e, ao mesmo tempo, constitui-se em um projeto de afirmação da liberdade, de desejo, de acolhimento na sociedade brasileira, tentativa de fazer a passagem da cidadania negada para a emancipação possível.

\footnotetext{
${ }^{43}$ ARRUTI $(2008$, p. 331)

${ }^{44}$ ARRUTI $(2008$, p.331).

45 ARRUTI $(2008$, p.328

46 MELO et al (2011, p.20)

47 Linhares (2004, apud FIABANI, 2012, p.403)

48 LEITE (2000, p.350)
} 
Assim "negar o quilombo como consequência direta da escravidão significa negar a própria essência da história do Brasil e a origem primeira da discriminação que a população afrodescendente vive no país"49.

O alargamento do conceito de quilombo - consequência das ressemantizações - permitiu que a esse conceito contemporâneo fossem incorporados outros agrupamentos como comunidades urbanas ou antigos assentamentos de reforma agrária, mas dentro de um único objetivo: agregar as atuais comunidades formadas por descendência negra como novos quilombos conferindo-lhes seus respectivos títulos dentro dos parâmetros da Constituição brasileira.

De acordo com o Ministério do Desenvolvimento Social, os quilombos estão assim definidos: "são grupos étnico-raciais, segundo critérios de auto-atribuição, com trajetória histórica própria, dotados de relações territoriais específicas e com ancestralidade negra relacionada com a resistência à opressão histórica sofrida, conforme Decreto n 4887/03.2" 50 .

\section{A Comunidade Quilombola de Orquídio Pereira}

A Comunidade Quilombola Orquídio Pereira está localizada no município de Jaguaquara, no território de identidade do Vale do Jiquiriçá, formado por 20 municípios. Os dados aqui apresentados foram construídos por meio de entrevistas com moradores mais velhos da comunidade.

Os moradores dessa comunidade passam nesse momento por muitas dificuldades e reclamam as suas terras para que possam construir outras casas adequadas para moradia - e também praticar a agricultura, fundamental para a subsistência.

A história da comunidade tem início no município de Itaquara-Ba, quando um fazendeiro residente na cidade chega de viagem trazendo quatro homens negros que fugiam da escravidão.

Os homens, que ficaram conhecidos como os ex-escravos ou os escravos

\footnotetext{
49 FIABANI $(2012$, p.402)

50 BRASIL (2003, Decreto $n^{\circ}$ 4887)
} 
fugidos ${ }^{51}$, desbravaram as matas das redondezas de Itaquara buscando um lugar adequado para desenvolver a agricultura para a sobrevivência do pequeno grupo que fora constituído ali.

Na luta pela sobrevivência, os 52irmãos - que haviam constituído família em meio às andanças - se separam. Alguns começaram a se instalar nas proximidades das fazendas que encontravam no caminho, onde prestavam serviço ao dono do latifúndio em troca de um pedacinho de terra para produzir.

Acontece que era muita gente para pouca terra; ou talvez "a terra não era pequena não, mais tinha gente demais" (Entrevista Dona Anália). As famílias cresciam e no lugarejo de nome "Lélio Andrade" - zona rural de Jaguaquara estava ficando difícil produzir para alimentar tanta gente.

Assim, as famílias começam a abandonar Lélio Andrade com destino à Jaguaquara, no intuito de encontrar lugares onde pudessem desenvolver a agricultura pensando na produção excedente que se transformaria em renda para o sustento dos seus pares.

Aí morava um bocado lá do outro lado, aí depois mudou pra cá, e a metade ficou lá, tem uma metade na rua da Lagoa, e outra em Itaquara...quer dizer não tá tudo junto, em tudo o que é lugar... (Entrevista Dona Anália)

Dentre os novos lugares escolhidos para a moradia, os descendentes dos africanos encontram na Rua Lindolfo Porto, Bairro Casca, no município de Jaguaquara-Ba, a chance de desenvolver as suas atividades agrícolas. Assim, a maior parte dos que migraram de Lélio Andrade se instalaram no final da Rua Lindolfo Porto.

Quando os primeiros descendentes chegam à Rua Lindolfo Porto, percebem que já existem moradores lá, então, a princípio, não ficaram muito próximos uns dos outros, espalhando-se nos lugares onde ainda havia possibilidade de construir suas moradias: "Não tem lugar aqui para habitar todo mundo, quer dizer que tá tudo espalhado aí pra cima" (Entrevista Dona Anália).

É nesse contexto de luta para a sobrevivência que a comunidade

51 Eles mesmos contavam que vieram da África e eram escravos até o dia em que conseguiram fugir

52 Os descendentes dos africanos que chegaram à Itaquara afirmam que eles eram irmãos. 
quilombola apresentada aqui vai tomando forma nos espaços delimitados pelo Bairro Casca, no final da Rua Lindolfo Porto.

A comunidade inicialmente recebeu o nome de Comunidade Quilombola Lindolfo Porto pelos primeiros visitantes que foram conhecer as famílias que residiam no final da Rua Lindolfo Porto. Em conversas informais os visitantes descobrem que a maioria dos moradores daquela comunidade são descendentes de "exescravos", então começam a anunciar a existência de uma comunidade quilombola no município.

A comunidade foi certificada pela Fundação Cultural Palmares em abril do ano de 2013. Durante o processo de certificação a presidente da associação da comunidade, Dona Anália, solicita que a comunidade seja registrada com o nome do seu avô - um dos escravos fugidos que chegam à Itaquara - Orquídio Pereira.

Para contar a história dos primeiros chegantes na comunidade, tomaremos como referência as narrativas de Dona Anália - atual presidente da Associação da Comunidade Quilombola Orquídio Pereira e nossa entrevistada - que, como neta de Orquídio Pereira, nos conduz na tessitura dos fatos.

Dos descendentes de africanos, quem primeiro chega a Lindolfo Porto é um tio de Dona Anália que se chamava Antônio. Outras pessoas da família acompanham Seu Antônio, incluindo sua mãe, a quem acompanha poucos meses depois: "Minha mãe veio primeiro. Depois de uns três meses eu vim".

As contas feitas por Dona Anália apontam que os primeiros descendentes chegaram à Rua Lindolfo Porto a cerca de 40 anos atrás. A família de Dona Anália veio para Jaguaquara em busca de melhores condições de vida e essa vontade (a melhoria de vida) foi plantada no coração dos que ficavam na roça, que esperavam a primeira oportunidade para seguir o caminho dos outros.

Aí os pessoal começou vim, começou vim, vem um hoje, vem oto amanhã, vem um hoje, otos amanhã, aí vêi tudo... os velhos foi morrendo tudo,os mais velhos foi morrendo tudo... (Entrevista Dona Anália)

Os pais de Dona Anália formaram família em Lélio Andrade, na zona rural do município de Jaguaquara. Dona Anália nos conta que as outras famílias, da mesma descendência, também moravam lá, mas era muita gente para pouco benefício: 
pouca terra, pouca produção, pouco alimento.

Ó, espia só... eu, quando cheguei logo, eu cheguei na roça onde eu morava, lá em Lélio Andrade, mas aí eu não me casei logo (...)Depois eu cheguei e depois resolvi me casar e fiquei morando no lugar do meu sogro (que é do pai dele aí ó) mas o lugar do meu sogro era um lugarzinho, é um lugar grande, mas só que já tinha muita gente. Tinha os filhos dele (né Neco?) tinha um bocado de gente lá morando. E meu pai também tinha um lugar lá também (...). Aí meu pai arrumou essa fazenda pra lá e foi morar lá, mas eu num foi, fiquei cá mais minha mãe. Em Lélio Andrade. Minha mãe, meu avô tinha um lugar lá e minha mãe morava lá. (Entrevista Dona Anália)

Dona Anália conta que a terra em que eles produziam em Lélio Andrade não era propriedade deles, não era uma terra pequena, porém não dava conta da quantidade de pessoas que havia para plantar e alimentar as suas famílias. Mesmo com as dificuldades que enunciam os seus discursos da época em que vivia em Lélio Andrade, Dona Anália lamenta a falta de terra para desenvolver a agricultura na comunidade em que reside atualmente:

Lá nós vivia de agricultura, porque lá a gente plantava mandioca, plantava feijão, plantava milho, é... impim, batata, plantava um bocado de coisa que a gente plantava...quer dizer que tirava pra fora pra vender né...e aqui, ninguém pode, tem nada...de que que a gente veve aqui? Só...Trabalhando pros ôto (...)(Entrevista Dona Anália).

As atividades desenvolvidas pelos aquilombados "o trabalhador escravizado escapado usufruía os produtos do seu esforço, empregado na agricultura, artesanato, caça, coleta, extrativismo, pesca, rapinagem, serviços, etc"53.

O quilombo - no seu conceito histórico - como o espaço de liberdade e autonomia era propício a essas atividades, no entanto as formações quilombolas históricas não estavam presas a terra (espaço físico geográfico), pois o elemento principal do quilombo é o sujeito - o escravo fugido.

A comunidade quilombola onde desenvolvemos a nossa pesquisa - que

53 FIABANI $(2012$, p.11) 
abarca o conceito de "quilombola" já 54ressemantizado - tem ainda como principal atividade no campo a agricultura. No entanto essa atividade não é apenas um símbolo da autonomia da comunidade, é a fonte de renda principal (talvez a única possibilidade para a obtenção de recursos financeiros). A produção é para o consumo da família e também para geração de renda, portanto a falta de terra para o plantio para eles significa falta de alimento.

A luta para a "sobrevivência" dos seus pares sempre foi o que motivou às idas e vindas de Dona Anália e sua família em fazendas alheias até o seu destino último na Rua Lindolfo Porto.

Assim, empenhada para acompanhar sua mãe no trajeto para Jaguaquara, a produção da sua última roça em Lélio Andrade virou moeda para comprar a tão sonhada ${ }^{55}$ posse na Rua Lindolfo Porto.

Depois eu me casei e continuei morando lá, né? Aí quando foi um dia, eu disse assim... que tinha muita gente, sei lá, num lugar só, acumulado, aí eu disse assim: Ô ${ }^{56} \mathrm{Neco}$, tá bom de nois comprar um lugar, uma casa pra nois morar, aí Neco veio aqui pra Jaguaquara. Nois tava com uma roça de mandioca, aí eu tava com a roça de mandioca e ele tava com uma roça de feijão, só o que tinha. Aí eu digo, nois vai juntar isso aqui tudo e vai comprar uma posse pra gente, tu vai lá em Jaguaquara e procura, vê se tu acha uma posse. Aífoi que ele veio e comprou uma posse lá do outro lado. Aí eu disse: lá pra o outro lado eu não vou! Que lá já tinha um bocado de ${ }^{57}$ gente da gente. Eu não vou não! Aí ele veio, pra esse lado de cá, aí topô um rapaz, já morreu, seu, seu Coringa, ele já morreu... ele morava ali em cima, ele tinha posse aqui embaixo, foi a que justamente aquela posse que eu morava ali, que era a ${ }^{58}$ minha casa lá ó... aí ele falou quanto era, ele falou o preço, aí ele foi em casa arrancou a mandioca, acho que apurou o feijão e trouxe pra rua, vendeu e deu o dinheiro o rapaz. (Entrevista Dona Anália)

\footnotetext{
${ }^{54}$ A ressemantização do termo quilombo foi uma iniciativa de antropólogos com o intuito de alargar o conceito de quilombo para abarcar o maior número de comunidades negras rurais possíveis na legislação referente às comunidades remanescentes de quilombos (FIABANI, 2012).

55 Expressão popular que designa um terreno, uma pequena porção de terra

56 Esposo de Dona Anália, sempre presente nas entrevistas concedidas

57 Gostaria de chamar à atenção para essa expressão usada por Dona Anália. Quando utiliza "gente da gente" está fazendo referência à sua família, aos descendentes de africanos que chegaram antes dela na comunidade.

58 A casa que Dona Anália faz referência na sua fala foi construída pelo seu esposo e foi onde criou os seus filhos, contudo a casa deteriorada e corre risco de desabar. Então Dona Anália e sua família estão morando em uma outra casa e aguardam uma posição da gestão pública municipal acerca dessa situação.
} 
Dona Anália compra a posse, mas não muda para Jaguaquara, pois ainda não tem condições de construir sua casa. No entanto sinaliza no seu discurso o incômodo que lhe traz conviver com muitas pessoas em um espaço de produção agrícola restrito, e conta que se mudou para morar com a sua mãe até consegui recursos para levantar a sua casa.

aí depois eu digo, ah sabe de uma coisa? e eu morava mais um bocado de gente no meu sogro, tinha gente demais... aí eu digo...esse negócio tudo embolado não dá certo não. aí eu cheguei e saí de lá, vim pra casa da minha mãe...cheguei e fiquei aqui junto com a minha mãe, depois minha tia, aqui tinha uma casa aqui, nesse mesmo lugar aqui, minha tia tinha uma casa e minha tia tinha ido embora pra roça, aí eu fiquei aqui nessa casa, aí nois veio pra aqui (...). (entrevista dona Anália).

Nos relatos de Dona Anália, ela expressa em todo o tempo a vontade que ela tinha em residir na Lindolfo Porto, que se faz pautada em duas situações: ficar perto da sua mãe (sua família) e usufruir do plantio da terra.

Ao chegar à Lindolfo Porto, Dona Anália percebe que o lugar que os seus familiares escolheram para a moradia já era habitado por outras famílias. As outras famílias são denominadas por Dona Anália como "diferentes".

Ó, diferente daqui da gente, é aí ó...Véi, que é fi de Dona Tevina, tinha o finado Joaquim, tinha o finado Duval, tinha o finado Hermes, tinha o finado Antônio, tinha Raquel que era dessa casa aqui, daqui da esquina, Raquel morava aqui...e, chovê, aqui nessa casa aí de junto morava o finado Osório que era uma posse que tinha aqui de junto, o finado Osório morava aqui, esses morador que tinha aqui era esses...(Entrevista Dona Anália).

Quando Dona Anália enuncia em sua narrativa expressões como "gente da gente" e "diferente daqui da gente" ela faz referência a composição dos membros daquela comunidade: "Nós e Eles"; e aponta quem são os atores dessa dicotomia lucidamente nas suas falas.

Segundo59 "ao se enfocar aquilo que é socialmente efetivo, os grupos étnicos passam a ser vistos como uma forma de organização social" e aponta que a característica crítica passa a ser a auto-atribuição e a atribuição por outros. Assim:

59 BARTH (2000, p.31) 
(...) A atribuição de uma categoria é uma étnica quando classifica uma pessoa em termos de sua identidade básica, mais geral, determinada presumivelmente por sua origem e circunstâncias de conformação. Nesse sentido organizacional, quando os atores, tendo como finalidade a interação, usam identidades étnicas para se categorizar e categorizar os outros, passam a formar grupos étnicos ${ }^{60}$.

A narrativa de Dona Anália enuncia a sua identidade étnica no momento em que utiliza expressões que se perfazem como marcadores étnicos. As características fenotípicas dos moradores da comunidade não são abordadas na narrativa de Dona Anália, contudo, quando ela faz uma separação entre a sua família, o que ela denomina como "os diferentes", separa e ao mesmo tempo se utiliza de um marcador étnico. Assim, as narrativas de Dona Anália apontam para a sua auto-atribuição identitária, pois em todo momento ela diz qual é o grupo a que ela pertence e qual é o outro grupo (os outros).

Dona Anália encontra um lugar peculiar em sua própria narrativa: "a gente". Ela nunca faz referência apenas a sua própria pessoa. Sempre faz referência a um grupo. O pensar na coletividade está sempre expresso nas narrativas de Dona Anália, que situa os membros da comunidade em seu discurso, evoca os nomes enquanto relata os fatos sobre a sua chegada na Comunidade de Lindolfo Porto e a permanência na comunidade quilombola.

(...) Se um grupo mantém sua identidade quando os seus membros interagem com outros, disso decorre a existência de critérios para determinação do pertencimento, assim como as maneiras de assinalar este pertencimento ou exclusão ${ }^{61}$.

Quando foi empreendido o processo para certificação, Dona Anália nomeia a comunidade como Orquídio Pereira, em homenagem ao seu avô. Contudo, mesmo constando em documento expedido pela FCP como Comunidade Orquídio Pereira, a comunidade quilombola, fundada há mais de quarenta anos, é conhecida no município como Comunidade Quilombola Lindolfo Porto.

(...) A gente pensava assim que a gente ia achar, porque a gente

60 BARTH (2000, p.32)

${ }^{61}$ BARTH (2000, p.34). 
num pensava que a gente ia,como era que a gente vinha...a gente pensava assim que ia ter um quintal grande pra gente plantar coisa, criar coisa, mas foi engano da gente... a gente vêi, depois a gente descobriu tinha essa fazenda aí, que é do finado Zinho antigamente, essa de cá era de seu Orlando, do lado de cima e aí pronto, a gente ficou no meio ali, e ta até hoje...não pode nem ir pra um lado, nem ir pra o outro...(Entrevista Dona Anália).

O caminho até a certificação foi marcado pelas contribuições das professoras Hilda Santos e Luíza Gonzaga. O processo de certificação da comunidade quilombola Orquídio Pereira foi iniciado em agosto de 2011; a efetivação do processo aconteceu dois anos depois e foi comemorado na comunidade com a presença de figuras do poder público municipal e outras autoridades.

A história da comunidade quilombola Orquídio Pereira começa de fato no município de Itaquara-Ba, quando Orquídio Pereira - avô de Dona Anália - chega ao município acompanhado da sua mulher e mais dois irmãos. Trazidos por um fazendeiro de nome Amancino - passam a trabalhar na zona rural da cidade.

Dona Anália relata que o seu avô contava que veio embora para fugir da escravidão, mas que em Itaquara ele não foi mais tratado como escravo. O exescravo constitui família e dentre os seus filhos está o pai de Dona Anália: José de Jesus.

Sobre os escravos fugidos:

Fugia o cativo doméstico, o trabalhador do eito, o ganhador especializado. Os fujões escapavam em grupos ou aos pares, mas sobretudo sozinhos, para visitar amigos e parentes; viver como negros livres libertos nas cidades e nos campos; procurar proteção de acoitador cúmplice; encontrar abrigo em um ermo do interiorb2.

Quando os familiares de Dona Anália chegam a ltaquara, toda região ainda era mata bruta. Dona Anália, por sua vez, deixou a comunidade na zona rural de Itaquara e com outros familiares decide morar em uma outra comunidade rural pertencente ao município de Jaguaquara - denominada Lélio Andrade.

O grupo instalado nas imediações de Lélio Andrade vivia da agricultura

\footnotetext{
62 FIABANI $(2012$, p.8)
} 
familiar, mas, com o tempo, as famílias foram crescendo e Dona Anália, percebendo que não tinha mais como realizar o plantio naquele local, segue viagem para Jaguaquara onde funda, despretensiosamente, a Comunidade Quilombola Lindolfo Porto.

O lugar escolhido para a moradia ficava entre o Rio Casca - importante para a plantação, utilizado para o banho e para lavagem de roupas - e uma linha férrea que passava por Jaguaquara e tinha como fim de linha o município de Jequié-Ba.

Quando a família de Dona Anália se instalou no bairro Casca, a linha férrea já estava desativada, mas os trilhos do trem ainda se encontravam em perfeito estado. A linha férrea dividiu a comunidade ao meio e as casas de taipa foram construídas com o barro que era escavado onde não havia trilhos. O resultado dessa escavação para a construção das casas é um barranco que atualmente passa por dentro da comunidade e refaz o caminho da linha do trem.

Hoje são mínimos os vestígios dos trilhos do trem. Quando chove muito forte as águas das chuvas trazem consigo o barro que vem desfazendo o barranco e invadindo as casas que estão sendo abandonadas pelos moradores que temem o desabamento das mesmas.

Dona Anália e seus familiares acreditavam que encontraria melhores condições para a sobrevivência aqui em Jaguaquara. Com a mesma expectativa, outros membros da família e agregados saíram de Lélio Andrade com a Jaguaquara, aumentando assim o contigente de membros da comunidade.

As condições de moradia dos membros da comunidade quilombola são precárias. Eles reclamam da situação e cobram providência do gestor público municipal, que prometeu construir novas casas para as famílias que ali estão alocadas.

Atualmente, a Comunidade Quilombola Orquídio Pereira é composta de cerca de vinte e sete famílias que ainda residem em casas de taipa e com poucos recursos para a sobrevivência.

O rio Casca, o principal atrativo para a escolha do local onde comunidade foi instalada, está poluído. Não há terras para o plantio, nem mesmo para a subsistência e os moradores reclamam por falta de trabalho.

E essas água daqui Milena, quando eu cheguei pra aqui, essa água 
daí, desse rio aí, essa água parecia uma água cristalina, a água era branquinha, alvinha, se tu vê! Tomava banhe, lavava roupa, tinha gente que inté bebia água ali, desse rio aí...era limpa, limpa limpa, precisa tu vê... e hoje em dia ta assim desse jeito aí ó...todo polvído, a gente não pode nem correr o dedo dentro... mas era alvinha essa água. (Entrevista Dona Anália).

Dona Anália e outros membros da comunidade às vezes vão para o "café" em fazendas vizinhas à comunidade, mas não é sempre que tem trabalho na roça. A maior parte dos jovens rapazes da comunidade tem migrado para Goiânia para trabalhar em roças de cana.

As mulheres da comunidade fazem artesanato, turbantes, fuxico, ponto de cruz, colocam aplique afro nos cabelos, fazem costuras à mão, fazem arte nas unhas e fazem doces. Porém não há dinheiro para o investimento no material para desenvolverem o trabalho e então não há como produzir renda.

Os membros da comunidade relatam que sobrevivem por meio de programas sociais do governo federal e da ajuda de entidades religiosas e/ou grupos políticos que distribuem cestas básicas e vestuário em períodos festivos como Natal e São João.

A comunidade sempre recebe doações, pois vivem em uma situação de precariedade, contudo não recebem doações de qualquer pessoa ou entidade. Afirmam que não querem esmolas, querem condições para trabalhar, querem a terra para praticar a agricultura.

Até hoje procurando uma forma de arrumar uma terra pra gente plantar...os meninos mesmo essa, foi pra o São João os meninos tava perguntando assim: ô tia los meninos que ta lá que é de minha cunhada também)...eles perguntando: Ô tia, a senhora não arruma um pedaço de terra aí não tinha?e eu digo ô, eu to lutano pra ver se eu arrumo, mas não consegui ainda não...ô tia, se a senhora arrumar uma terra aí, a senhora me liga que eu vou me embora pra lá...tivemo uma terra pra gente plantar, né? ... (silêncio) ... mas, infelizmente, enquanto eu disse a ele, num arrumei... até hoje. (Entrevista Dona Anália).

Os homens da comunidade ainda praticam a caça, que serve para o alimento. Em algumas casas há o altar dos santos, com velas sempre acesas. Os moradores da comunidade constituem um grupo étnico que tem lutado pelos seus direitos, pela sobrevivência e permanência do grupo, assim percebemos que, 
mesmo com as ressemantizações, "os quilombos continuam representando a resistência negra"63.

\section{Considerações finais}

As pesquisas sobre comunidades quilombolas tem se intensificado nos últimos anos e contribuído para o trazer ao público os conhecimentos ancestrais, as práticas culturais, as memórias e práticas curriculares/pedagógicas nelas desenvolvidas.

Neste artigo, tomando como base as memórias de moradores em uma perspectiva benjaminiana, apresentamos a história da comunidade quilombola Orquídio Pereira, localizada no município de Jaguaquara.

As narrativas dos moradores relatam o surgimento da comunidade, as dificuldades para a posse da terra, as variadas situações de exclusão social a que estão expostos. Da mesma forma, os relatos apontam para a necessidade de pesquisas que dêem visibilidade aos quilombolas, grupo étnico que demanda cada vez mais políticas públicas por parte do Estado brasileiro, principalmente no atual contexto de esvaziamento das políticas para determinados grupos.

\section{Referências}

ARRUTI, José Maurício. Quilombos. In: SANSONE, Lívio; PINHO, Osmundo Araújo (org.). Raça: novas perspectivas antropológicas. Salvador: EDUFBA, 2008. p. 315351.

BARTH, Fredrik. O guru, o iniciador e outras variações antropológicas. Rio de Janeiro: Contra Capa Livraria, 2000.

BENJAMIN, W. Magia e técnica, arte e política. 7.ed. São Paulo: Ed. Brasiliense, 1994.

BRASIL. Constituição da República Federativa do Brasil de 1988. Ato das Disposições Constitucionais Transitórias: Art. 68. Brasília, DF, 1988.

63 FIABANI (2012, p.29). 
BRASIL. Decreto n 4.887 de 20 de novembro de 2003. Diário Oficial da República Federativa do Brasil. Brasília, DF, 2003.

DÓCIO, A. A.; PEROVANO FILHO, N. Extensão universitária é ato de aquilombor-se na contemporaneidade. ODEERE - Revista do Programa de Pós-Graduação em Relações Étnicas e Contemporaneidade, vol. 4, n. 8, p. 338-363, 2019. DOI: https://doi.org/10.22481/odeere.v4i8.6241

FERREIRA, Graziele N. Cinzento: memória de uma comunidade negra remanescente de quilombo. 195f. Dissertação (Mestrado em Ciências Sociais). Pontifícia Universidade Católica de São Paulo, São Paulo, 1999.

FIABANI, Adelmir. Mato, palhoça e pilão: o quilombo, da escravidão às comunidades remanescentes (1532-2004). 2.ed. São Paulo: Expressão Popular, 2012.

LEITE, Ilka, Boaventura. O projeto político quilombola: desafios, conquistas e impasses atuais. Revista Estudos Feministas, Florianópolis, vol.16, n.3, p.965-977, 2008. DOI: https://doi.org/10.1590/s0104-026×2008000300015

LEITE, Ilka Boaventura. Os quilombos no Brasil: questões conceituais e normativas. Etnográfica, Lisboa, v. IV, n. 2, p. 333-354, 2000.

LIMA, Vivian I. Raízes, frutos e tramas: pertencimentos, relações étnicas e saberes na comunidade quilombola do Baixão (Vitória da Conquista - Ba). $124 \mathrm{f}$. Dissertação (Mestrado em Relações Étnicas e Contemporaneidade). Universidade Estadual do Sudoeste da Bahia, Jequié, 2018.

MELO, Ana Lúcia Aguiar et al. "Palmas" para o quilombo: processo de territorialidade e etnicidade negra. Santa Maria: Ed. da UFSM, 2011.

O'DWYER, Eliane Cantarino (Org.). Quilombos: identidade étnica e territorialidade. Rio de Janeiro: FGV, 2002.

OLIVEIRA, R. F. Índios Paneleiros no Planalto da Conquista: do massacre e o (quase) extermínio aos dias atuais. 221f. Dissertação (Mestrado em História). UFBA, Faculdade de Filosofia e Ciências Humanas, Salvador, 2012. 
OLIVEIRA, C. A. Quenta Sol: a história e a memória de uma comunidade negra através da sua oralidade. 139f. Dissertação (Mestrado em História). Universidade Estadual Paulista, Franca, 2010.

SEIXAS, Jaci. Percursos de memórias em terras de história: problemáticas atuais. In: BRESCIANI, Stella e NAXARA, Márcia (Orgs.). Memória e (res)sentimento: indagações sobre uma questão sensível. Campinas: Ed. Unicamp, 2001.

Benedito Eugenio: Possui graduação em licenciatura em Pedagogia pela Universidade do Estado da Bahia (2002), graduação em Licenciatura em Letras pela Faculdade de Tecnologia e Ciências (2010), mestrado em Educação pela Pontifícia Universidade Católica de Minas Gerais (2004) e doutorado em Educação pela Universidade Estadual de Campinas (2009). Atualmente é professor Titular da Universidade Estadual do Sudoeste da Bahia, atuando na graduação, no Programa de Pós-Graduação-Mestrado Acadêmico em Relações Étnicas e Contemporaneidade, do qual foi Vice-coordenador (2014-2016) e Programa de Pós-Graduação em Ensino (PPGEN). Coordenador do Programa de PósGraduação em Ensino (PPGEN- 2017). Foi docente do PPG Educação/UESB (2013-2014). Coordena, desde 2011, o curso de Especialização em Educação e Diversidade Étnicocultural. Tem experiência na área de Educação, com ênfase em Currículos Específicos para Níveis e Tipos de Educação, atuando principalmente nos seguintes temas: currículo (políticas e práticas pedagógicas para a educação básica), pesquisa, livro didático, educação das relações etnicorraciais, relações de raça e gênero na escola, políticas públicas e educação escolar quilombola.

Milena Lima Tamborrielo: Graduada em Pedagogia (UESB). Coordenadora Pedagógica da Rede Estadual de Ensino da Bahia.

Rubia Cristina Nóbrega: Graduada em Pedagogia (UESB) e em Matemática. Mestranda em Relações Étnicas e Contemporaneidade (UESB). Professora de Matemática da Rede Estadual de Ensino da Bahia.

Juliana Brito dos Santos: Graduada em Licenciatura em Educação Física (UFRB). Pósgraduada em Educação e Interdisciplinaridade (lato sensu) pela Universidade Federal do Recôncavo da Bahia-CFP/ UFRB (2019). Atualmente professora pela Faculdade de Ciências e Empreendedorismo/FACEMP na cidade de Santo Antônio de Jesus/Ba. Mestranda em Relações Étnicas e Contemporaneidade (UESB).

(9) $\stackrel{(0)}{\mathrm{ir}}$ This work is licensed under a Creative Commons Attribution 4.0 International License.

(c) (1) Este trabalho está licenciado com uma Licença Creative Commons - Atribuição 4.0

Internacional.

Artigo recebido para publicação em: 30 de abril de 2020.

Artigo aprovado para publicação em: 23 de maio de 2020. 